\title{
Moral Judgment: An Overlooked Deficient Domain in Multiple Sclerosis?
}

\author{
Samar S. Ayache 1,2,3(1) and Moussa A. Chalah $1,2, *(1)$ \\ 1 EA 4391 Excitabilité Nerveuse et Thérapeutique, Université Paris-Est, 94010 Créteil, France; \\ samarayache@gmail.com or samar.ayache@u-pec.fr \\ 2 Service de Physiologie-Explorations Fonctionnelles, Hôpital Henri Mondor, Assistance Publique-Hôpitaux \\ de Paris, 94010 Créteil, France \\ 3 Neurology Division, Lebanese American University Medical Center-Rizk Hospital (LAUMC-RH), \\ 1100 Beirut, Lebanon \\ * Correspondence: moussachalah@gmail.com or moussa.chalah@u-pec.fr; Tel.: +33-1-49-81-46-62
}

Received: 28 September 2018; Accepted: 13 November 2018; Published: 16 November 2018

\begin{abstract}
Multiple sclerosis (MS) is a chronic inflammatory and neurodegenerative disease of the central nervous system through which patients can suffer from sensory, motor, cerebellar, emotional, and cognitive symptoms. Although cognitive and behavioral dysfunctions are frequently encountered in MS patients, they have previously received little attention. Among the most frequently impaired cognitive domains are attention, information processing speed, and working memory, which have been extensively addressed in this population. However, less emphasis has been placed on other domains like moral judgment. The latter is a complex cognitive sphere that implies the individuals' ability to judge others' actions and relies on numerous affective and cognitive processes. Moral cognition is crucial for healthy and adequate interpersonal relationships, and its alteration might have drastic impacts on patients' quality of life. This work aims to analyze the studies that have addressed moral cognition in MS. Only three works have previously addressed moral judgement in this clinical population compared to healthy controls, and none included neuroimaging or physiological measures. Although scarce, the available data suggest a complex pattern of moral judgments that deviate from normal response. This finding was accompanied by socio-emotional and cognitive deficits. Only preliminary data are available on moral cognition in MS, and its neurobiological foundations are still needing to be explored. Future studies would benefit from combining moral cognitive measures with comprehensive neuropsychological batteries and neuroimaging/neurophysiological modalities (e.g., functional magnetic resonance imaging, tractography, evoked potentials, electroencephalography) aiming to decipher the neural underpinning of moral judgement deficits and subsequently conceive potential interventions in MS patients.
\end{abstract}

Keywords: multiple sclerosis; moral decision-making; social cognition; alexithymia; theory of mind; empathy

\section{Introduction}

Multiple sclerosis (MS) is a chronic progressive disease of the central nervous system (CNS) characterized by demyelination, synaptopathy, and neurodegeneration involving the brain and spinal cord [1-3]. It is the main cause of nontraumatic disability in young adults [1]. Its precise etiology remains unclear and includes a constellation of mechanisms. The mobilization of peripheral immune cells and their access to the CNS through an impaired blood-brain barrier appears to play a key role in MS pathogenesis, based on studies showing mainly macrophages and CD8+ T cells but also CD4+ T cells, B cells, and plasma cells in MS lesions [2-4]. 
MS can clinically manifest as three types: the relapsing remitting (RR) type, which is characterized by periods of acute symptoms onset separated in time by periods of full or partial recovery; the primary progressive (PP) type, which entails a steady progressive evolution of the disease since its onset; and the secondary progressive (SP) type, which is the conversion of the RR type into a pattern of progressive clinical worsening $[2,4,5]$. During the course of the disease, patients can report motor, sensory, and cerebellar symptoms but can also suffer from cognitive, emotional, and behavioral manifestations [1,2,6-13].

Although cognitive deficits are common in MS patients, affecting up to $65 \%$ of them, little attention has been paid to cognitive and behavioral performance in this population [13]. Among the most frequently impaired cognitive domains are attention, information processing speed, and working memory, which have been extensively addressed in this population. However, less emphasis has been placed on social cognition, which entails the individual's abilities to recognize others' emotions, intentions, and beliefs (i.e., facial and bodily emotion recognition, theory of mind (ToM)) and the capacity to empathize with others (i.e., empathy). Social cognition is crucial for healthy social functioning and deficits in this capacity may affect the quality of life [13]. Social cognitive deficits might be behind altered social interactions, high prevalence of social anxiety, and increased rates of unemployment and divorce observed among MS patients [13]. Moreover, some of the latter issues could result from a social reconfiguration within a family, where healthy members would face the obligation to deal with MS-related physical and cognitive consequences [14].

In addition to social cognition deficits, MS patients also exhibit high prevalence of alexithymia, which is a multicomponent personality trait implying difficulties to understand and describe one's emotions and an externally oriented thinking (EOT) [8]. Although this trait can affect around $10 \%$ of the general population, its prevalence in MS patients can reach 53\% [8]. This highlights the difficulties of MS patients to understand their own emotions as well as to understand others' emotions and to subsequently empathize with them [8].

Besides these socio-affective domains, moral judgment is a complex cognitive sphere that enables individuals to judge others' actions. It is defined by the set of habits and values that orient the social conduct in a certain group [15]. Moral reasoning relies on conscious processes in charge of transforming given information about actions by comparing them to a set of virtues, with the aim of attaining a moral judgement [15]. If deficits in moral judgment occur in MS, they would be very debilitating for patients and their social circle.

The main objective of the present work is to shed light on studies that assessed moral judgment in patients with MS. We will first define the selection criteria of this work. Afterwards, a brief overview of the available data on the underlying mechanisms of moral cognition and its assessment will be presented. This will be followed by an analysis of the studies that considered moral judgment in MS. Plausible underlying mechanisms of moral judgment deficits in MS will be tackled in the light of the available findings. Finally, some recommendations will be provided for future studies in order to improve the current understanding of these deficits.

\section{Study Selection}

Computerized databases (MEDLINE/PubMed, Scopus) were consulted, and a search was conducted independently by both coauthors according to the Preferred Reporting Items for Systematic Reviews and Meta-analyses (PRISMA) guidelines [16] with the aim to identify original research articles published at any time until 28 August 2018, in English and French languages, regarding moral judgement in MS patients. The following key terms were used: ('moral judgement' OR 'moral judgment' OR 'moral cognition' OR 'moral competence') AND ('multiple sclerosis' OR 'MS'). Both authors screened the titles, abstracts, and full texts of all references retrieved in the searches and determined the eligibility and possible inclusion of each article. In cases of uncertainty, the full text of the manuscript in question was assessed by both authors and a final decision was made concerning inclusion/exclusion. Additional citations were searched by scanning the references of 
selected papers. Three publications matched the selection criteria and consisted of case-control studies that compared moral judgment between MS patients and healthy controls. They also included some neuropsychological measures, but none assessed the neurobiological underpinnings of moral judgment by means of neuroimaging or neurophysiological modalities. A flow diagram of the research method is illustrated in Figure 1 [16].
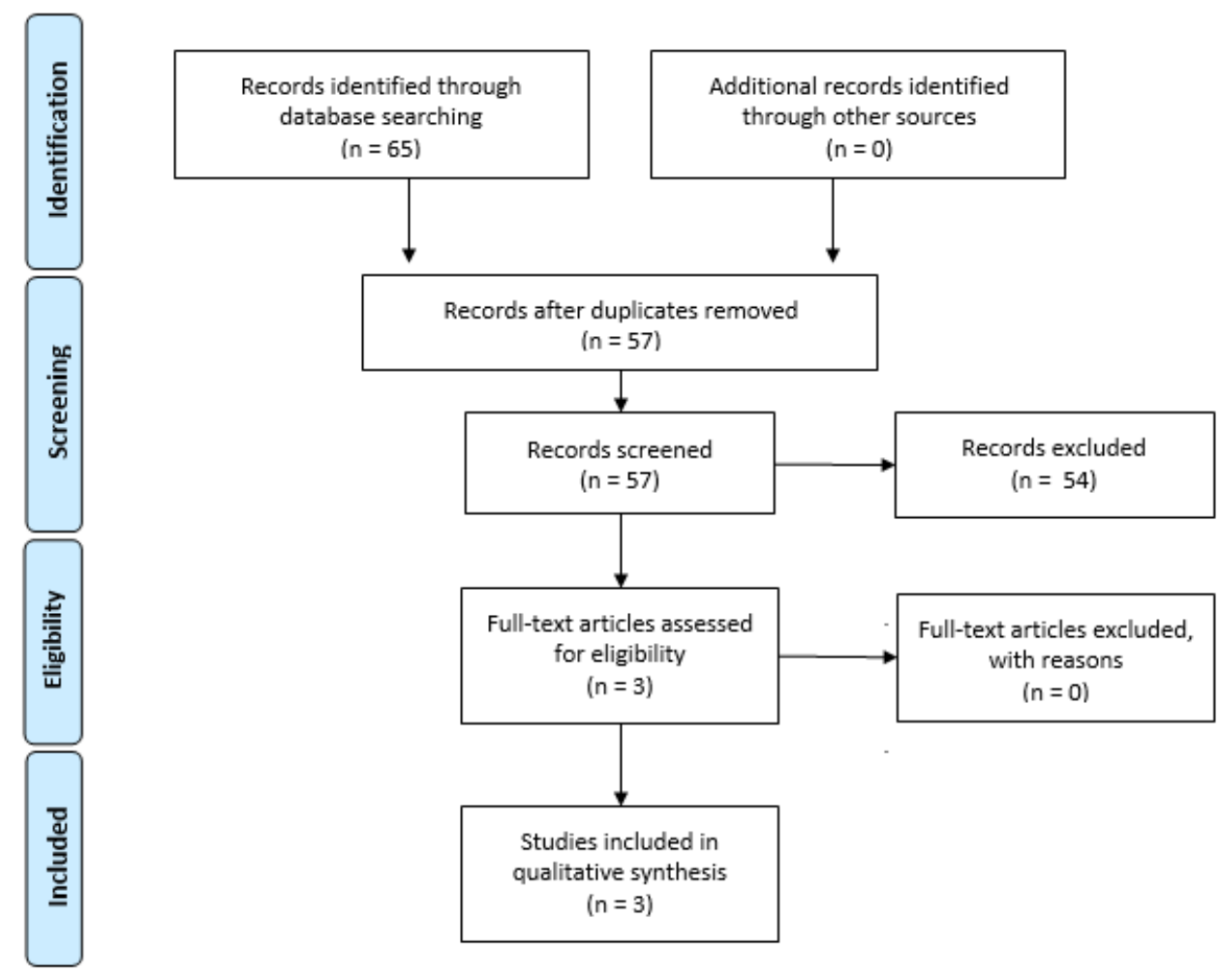

Figure 1. Flow diagram of the adapted research method.

\section{A Brief Overview of the Neurobiology of the Moral Brain}

Processing morality seems to involve complex brain networks that exhibit a certain degree of overlapping with those devoted to other emotional, cognitive, and behavioral processes, including basic (e.g., attentional control, executive functions) and social cognition (i.e., emotion processing, ToM, empathy) [17]. These circuitries involve cortical (e.g., frontal, temporal, parietal, and cingular regions) and subcortical (e.g., basal ganglia and amygdalo-hippocampal complex) regions [17,18]. In MS, no structural or functional imaging studies have assessed the neurobiological correlates of moral judgment. For this reason, this section will briefly reappraise the cerebral substrates of this domain as derived from studies in healthy subjects and clinical populations other than MS.

Nowadays, one of the most accepted models in philosophy, psychology, and biology research explains moral cognition in the light of the dual-process theory, which is supported by clinical and behavioral data $[17,19,20]$. The theory entails the existence of two distinct systems that compete during the generation of a moral judgement $[17,19]$. The first one is an automatic, quick, intuitive, and emotion-driven deontological system with feature-specific sensitivity during a situation; the second one is a slow, cognitive, explicit, and deliberative system that reasons about utilitarian consequences $[19,21-26]$. In other words, a second reasoning system is deployed to correct the initial intuitions or emotional impulses.

However, the mode of interaction between these two systems remains controversial [17]. In fact, both systems seem to have non-overlapping dissociable neural substrates that work in an independent and parallel manner. In other words, judging a moral dilemma seems to involve, on the one side, the orbital and ventromedial parts of prefrontal cortex (PFC) and, on the other side, areas such as 
the dorsolateral PFC and the parietal cortex [27]. While the former areas deal with the autonomic emotional aversion to harm, the latter influence the cognitive rational control process; a process that engenders a cognitive propensity and maximizes the welfare regardless of cost $[17,18,21,27-29]$. In this context, the anterior cingulate cortex (ACC) intervenes to ensure that the conflict between the ventromedial and dorsolateral PFC is solved [17,21,27].

Besides the abovementioned dual-process model, other authors, like Cohen and Ahn, propose a single-process model, which they called 'the subjective utilitarian theory' of moral judgment [20]. It entails the presence of a single process by which an individual makes moral decisions. Here, the competition will occur between similarly valued items rather than between two distinct decision processes (e.g., a moral dilemma denoting the death of one's own child versus the death of five of his/her friends). The proposed system is concerned with identifying and saving the item with relatively higher personal value [20] (i.e., the child would likely survive in the proposed dilemma). The more the items resemble each other, the more difficult the decision is.

Furthermore, some researchers consider that moral cognition puts into action multiple processes, which may challenge the previous models and propose a shift toward a 'dynamic system model' of moral cognition [30]. One of the arguments supporting this notion lies in the fact that the dual-process theory cannot fully explain, for instance, why modulating/altering the function of the dorsolateral PFC yielded opposing results across the studies (i.e., resulting in more utilitarian judgment versus less utilitarian judgment depending on the studies) [31]. Such a finding suggests an 'integration-and-selection' function rather than a restricted 'rational cognitive control' function of the dorsolateral PFC [31]. In other words, instead of exclusively having a cognitive control function, the dorsolateral PFC may be able to select a specific moral response among the available options and integrate information about utilitarian consequences and moral rights with dilemma-specific contents following moral rules. Based on these findings, moral judgment may constitute a dynamic process that puts into action several mental computations that are devoted to processing self-related (e.g., personal goals and identities) and others-related information (e.g., others' mental states, social norms, social categories, reputational information) [30]. In a recent activation likelihood estimation metanalysis, the authors concluded that moral judgment recruits (i) a series of brain areas (e.g., medial PFC, lateral orbitofrontal cortex, temporoparietal junction (TPJ), amygdala, precuneus) that are common to all moral tasks and (ii) unique networks devoted to each of the moral modalities such as mentalizing method (affective versus cognitive ToM), instructional cues (instructing the individual to focus on morally (explicit) versus non-morally (implicit) salient information), role (i.e., self versus other, victim versus agent), and proximity (i.e., psychological versus imagined physical distance separating perpetrator from victim) [31]. Other works also found that a higher engagement in ToM abilities (recruitment of TPJ, precuneus and dorsomedial PFC) occurs when facing psychological versus physical harm, although both types activate the same brain regions [32,33]. These findings support the concept of a dynamic and multi-process moral judgment network and might account for the difference in brain activation pattern across moral judgment studies.

Adding to studies that explored the neural substrates of moral cognition, few available physiological reports have proposed a link between autonomic physiological responses and morality. For instance, utilitarian moral judgment was found to be associated with low heart rate variability (low cardiac vagal tone) [34,35] or low ability to generate skin conduction response (a somatic index of affective state/autonomic arousal) [36,37]. This perhaps reflects low neurovisceral integration at the level of PFC at the basis of the utilitarian pattern of response. Conversely, deontological moral judgment was found to be associated with high peripheral vasoconstriction/total peripheral resistance, a vascular measure that may reflect good/high visceral reactions [38].

It is also worth noting that some variables might contribute to moral judgment such as genetic variations (e.g., CAG polymorphism in androgen receptor gene [39], oxytocin receptor gene [40,41]), neuroendocrine factors (e.g., neuropeptide oxytocin [42], hypothalamic-pituitary-adrenal (HPA) 
axis [18]), neurotransmitters (e.g., serotonin, dopamine, noradrenaline [18,43-46]), environmental conditions (e.g., geographical area, climate, stress), and sociocultural conditions (e.g., gender) [18,47,48].

\section{Exploration of Moral Judgment}

Quantifying moral judgment is possible via several tools such as moral dilemmas [36]. These dilemmas consisted of situations where every possible course of action would breach some otherwise binding moral principles [49]. Common adopted scenarios involve harming an individual for the welfare of a group of subjects. Accepting such a behavior may reflect a utilitarian pattern of moral judgment (utility of scarifying one person for the sake of sparing a majority), which is driven by a detailed cost-benefit analysis, while unaccepting such a behavior might derive from an instinctual aversion toward harm [21,27].

The 'Footbridge' and the 'Trolley' stand among the most famous and ubiquitous moral dilemmas [37,49-52]. Both well illustrate the conflict between the utilitarian and deontological appraisals. The 'Footbridge' dilemma proposes two responses: (i) a utilitarian one that is supported by cognitive processes and favors pushing someone off of a foot bridge into the path of a runaway trolley in order to save five lives and (ii) an alternative nonutilitarian response driven by automatic emotional processes and entails sparing the man and allowing the others to die $[23,53,54]$. In the 'Trolley' dilemma, individuals have to choose between (i) doing nothing and allowing the trolley to move forward and kill five people tied-up on its track (nonutilitarian response), or (ii) redirecting the track by hitting a switch, this action would save the attached people but would result in scarifying the life of a single person lying on the side track (utilitarian response). While the Footbridge dilemma is personal (directly killing the man by pushing him into the path of a trolley), the Trolley dilemma is impersonal, since the decision of the responder would indirectly result in killing an individual by pulling a lever that will stop an arriving carriage that would otherwise kill five people $[27,29,55,56]$.

Other moral dilemmas propose some situations/stories where an agent cannot fulfill the moral requirements in question. Here, participants are usually asked to perform several ratings including their degree of acceptance of the agent's behavior (i.e., moral acceptability/permissibility), the pleasantness/unpleasantness of the experience (i.e., emotional valence), and their response to the exposed scene (i.e., emotional arousal/reactivity) [57]. Besides these dilemmas, scrutinizing moral judgement is feasible by presenting pictures or visual sentences $[21,58,59]$ or by employing questionnaires [60].

\section{Moral Cognition in Multiple Sclerosis Studies}

Three studies have addressed moral cognition in patients with MS [61-63]. In the first one [61], Gleichgerrcht and colleagues employed a series of moral vignettes adapted from Greene and colleagues' battery of moral dilemmas [21,27]. The stories assess (i) the individual's ability to accept hurting others in an attempt to benefit a majority of persons (moral permissibility), (ii) the amount of one' emotional reaction in front of a moral dilemma (emotional reactivity), and (iii) the extent of the individual's egocentric perception of others' attitudes with regard to presented moral scenarios (i.e., to which extent others may rate the act in a similar manner: moral relativity). The study also included measures of alexithymia and empathy. Compared to healthy controls, MS patients exhibited altered moral judgment, high alexithymia, and low empathy scores. They significantly differed from healthy controls by having a decreased moral permissibility as well as increased moral relativity and emotional reactivity. Results on moral dilemmas among patients may be related to socio-emotional domains such as alexithymia and empathy, based on some evidence supporting a relationship between alexithymia, social cognition, and moral judgment [64-67]. However, it is important to note that the direction of this relationship is somehow intriguing in MS patients since, in other clinical populations, low empathic abilities and high alexithymia were linked to utilitarian rather than deontological moral judgment $[29,68-73]$, warranting further explorations. 
Another contributory factor to low moral permissibility might be stress, which was previously found to correlate with less utilitarian moral judgment [48]. In fact, due to the unpredictable course and events in MS, the latter constitutes a chronic stressful condition through which patients may frequently experience fears and anxiety related to the uncertainty of the disease consequences. For instance, they might be afraid of getting irreversible disability during an MS relapse and might be afraid to experience a new MS attack while they are in remission [62]. In this context, the activation of stress response might have dictated the appearance of non-utilitarian judgment in this cohort.

From a neurobiological perspective, the dual-process model may suggest that the non-utilitarian pattern reported in MS patients is due to higher ventromedial PFC and/or lower dorsolateral PFC activity, especially in considering that MS pathophysiology is known to affect the frontal networks [74-76]. However, it is difficult to confirm this speculation since no MS study has included neuroimaging measures to examine the link between frontal circuits integrity and moral judgment capacities. Nevertheless, some studies have addressed the neural substrates of social cognition, which may be also shared by and/or contribute to moral judgment performance. These works have linked social cognitive deficits to diffuse white matter pathologies [77-80] as well as gray matter atrophy (involving the amygdala [81], cingulate cortex [79], left temporal pole, and left fusiform facial area [80]). Additional evidence has been derived from functional magnetic resonance imaging (MRI) studies where patients' performance on social cognition tasks was associated with abnormal pattern of activation in the left insula (hypoactivation [77]), left ventrolateral PFC (hypoactivation [77] or hyperactivation [82]), and precuneus and posterior cingulate cortex (hyperactivation [83]) or decreased functional connectivity between the amygdala and the ventrolateral/medial PFC [82]. Admitting the relationship between social and moral cognition, these brain areas might overlap with those devoted to moral cognition and merit future research. In addition, other factors may have also contributed to patients' performance, including neuroendocrine dysfunction and neurotransmitters imbalance, since the latter have been previously described in MS [7] and were found in some studies to be associated with moral judgment performance [18,43-46].

Besides moral permissibility, heightened emotional reactivity might be related to a dysfunction of emotion regulation, which has been previously reported in MS [84-87]. It might also be related to arousal/autonomic reaction. Therefore, it could be interpreted in the light of the aforementioned neurophysiological studies that addressed moral cognition, which featured a relationship between high physiological reaction and non-utilitarian moral judgment [38]. This relationship could explain the observed findings (i.e., low permissibility) in this MS cohort.

A second study by the same team was interested in understanding MS patients' attitudes towards third-party violations [62]. Patients were exposed to 24 unique stories adapted from Young and colleagues' work [88]. After each scenario, the MS patients were asked to rate (i) how much the agent's action was appropriate, (ii) how severe the agent should be punished, and (iii) to which extent other people may respond to this scenario in a similar manner as them. Similar to the previous work, patients reported higher alexithymia ratings and lower empathy scores compared to healthy controls. Although they did not differ from healthy controls in their moral judgment of some acts, they had higher levels of emotional reactivity, judged others' behavior to be less appropriate, and attributed more punishments for them. Such an outcome was driven by the EOT dimension of alexithymia, which could be defined as a concrete, introspection-devoid, reality-based, and literal thinking along with a tendency to avoid active conflict resolution [8]. Again, some research has suggested that, in the face of the traumatic nature of the disease, one of the adapted coping strategies by MS patients could be to orient their thinking on external events rather than paying attention to their inner feelings $[13,89,90]$. Therefore, EOT may emerge as a cognitive adaptive strategy that protects individuals from MS-related stress by avoiding self-reflection, distracting attention from self-oriented ruminations, and blunting the influence of negative arousal states [91,92]. Another plausible explanation would be that stricter moral attitude toward others could be related to frequently encountered symptoms in MS such as 
fatigue, depression, anxiety, and deficits in ToM or other cognitive domains, all of which were not addressed in this work and deserve to be addressed in future works [6-8].

In a third recent study, Realmuto and colleagues reported that their MS patients had comparable moral judgment performance relative to healthy controls but exhibited lower moral permissibility on instrumental dilemmas [63]. However, unlike the previous works, which documented high emotional reactivity in MS patients, the third study reported low emotional arousal in the recruited cohort. Such a finding may reflect emotional detachment, which might serve as a coping strategy aimed toward adapting to social contexts and maintaining a certain quality of life [93]. Moreover, levels of empathy and alexithymia, both of which were associated with moral performance in the previous two studies, were not assessed in this third study and might have mediated the observed discrepancy in emotional response. The difference in employed moral stimuli across these studies may constitute an additional explanation for the observed mismatch in emotional arousal/reactivity.

A summary of these studies is available in Table 1. 
Table 1. A summary of studies assessing moral cognition in patients with multiple sclerosis (MS).

\begin{tabular}{|c|c|c|c|}
\hline Study & Gleichgerrcht et al., 2015 [61] & Patil et al., 2017 [62] & Realmuto et al., 2018 [63] \\
\hline \multirow{9}{*}{$\begin{array}{l}\text { Patients' demographic } \\
\text { and clinical data }\end{array}$} & 38 RR MS patients & 38 consecutive RR MS patients & 45 RR MS patients \\
\hline & $87.30 \%$ females & $86.80 \%$ females & $68.89 \%$ females \\
\hline & Mean age: $42.3 \pm 11.3$ years & Mean age: $42.3 \pm 11.3$ years & Mean age: $34.22 \pm 7.65$ years \\
\hline & All receiving immunomodulatory drugs & All receiving immunomodulatory drugs & Immunomodulatory treatment: details N/A \\
\hline & Mean education level: $15.4 \pm 2.8$ years & Mean education level: $15.4 \pm 2.8$ years & Mean education level: $13.49 \pm 2.46$ years \\
\hline & Mean EDSS score [94]: $1.66 \pm 1.6$ & Mean EDSS score [94]: $1.66 \pm 1.6$ & Mean EDSS score [94]: $2.06 \pm 1.46$ \\
\hline & Mean disease duration: $1.6 \pm 8.7$ years & Mean disease duration: $10.60 \pm 8.7$ years & Mean disease duration: $9.72 \pm 6.22$ years \\
\hline & Mean number of relapses: $3.4 \pm 1.92$ & Mean number of relapses: $3.4 \pm 1.92$ & Mean number of relapses: details N/A \\
\hline & Mean MSSS score [95]: $2.35 \pm 2.4$ & Mean MSSS score [95]: $2.35 \pm 2.4$ & Mean MSSS score [95]: $2.85 \pm 2.59$ \\
\hline Healthy control group & $\begin{array}{l}38 \text { age--, gender-, and education-matched } \\
\text { healthy controls }\end{array}$ & $\begin{array}{l}38 \text { age-, gender-, and education-matched } \\
\text { healthy controls }\end{array}$ & $\begin{array}{l}45 \text { age--, gender-, and education-matched } \\
\text { healthy controls }\end{array}$ \\
\hline $\begin{array}{l}\text { Assessment tool for } \\
\text { moral judgement }\end{array}$ & $\begin{array}{l}\text { Moral dilemma task: a series of eight } \\
\text { vignettes from Greene et al.'s } \\
\text { battery }[21,27] \text { presenting situations } \\
\text { measuring moral permissibility, } \\
\text { emotional reactivity, and moral relativity }\end{array}$ & $\begin{array}{l}\text { Moral intent task: } 24 \text { unique stories } \\
\text { adapted from Young et al. } 2010 \text { [74] }\end{array}$ & $\begin{array}{l}\text { Moral dilemmas including instrumental and } \\
\text { incidental conditions [57] }\end{array}$ \\
\hline Other measures & $\begin{array}{l}\text { Alexithymia: TAS [96] } \\
\text { Empathy: IRI [97] }\end{array}$ & $\begin{array}{l}\text { Alexithymia: TAS [96] } \\
\text { Empathy: IRI [97] }\end{array}$ & $\begin{array}{l}\text { Non-social cognition evaluation: BICAMS [98], } \\
\text { Cognitive Estimation task [99], and Stroop test [100] } \\
\text { Social cognition evaluation: Ekman-60 Faces test, } \\
\text { RMET, and Story-based Empathy task [101,102]. } \\
\text { Quality of life: MuSIQoL [103] } \\
\text { Fatigue: FSS [104] } \\
\text { Depression and anxiety: HADS [105] }\end{array}$ \\
\hline
\end{tabular}


Table 1. Cont

\begin{tabular}{|c|c|c|c|}
\hline Study & Gleichgerrcht et al., 2015 [61] & Patil et al., 2017 [62] & Realmuto et al., 2018 [63] \\
\hline Group comparison & $\begin{array}{l}\text { Patients exhibited reduced moral } \\
\text { permissibility, increased moral relativity, } \\
\text { increased emotional reactivity, low } \\
\text { empathy, and high alexithymia rating } \\
\text { compared to healthy controls }\end{array}$ & $\begin{array}{l}\text { Compared to healthy controls, patients } \\
\text { had comparable levels of moral } \\
\text { judgement but exhibited reduced moral } \\
\text { permissibility, increased moral relativity, } \\
\text { increased emotional reactivity, low } \\
\text { empathy and high alexithymia ratings }\end{array}$ & $\begin{array}{l}\text { No significant group differences in the levels of } \\
\text { moral judgment (rate of yes/no response in } \\
\text { dilemmas resolution; attribution of emotional } \\
\text { valence to moral actions) but had lower moral } \\
\text { permissibility and emotional arousal (for the } \\
\text { instrumental dilemmas } \\
13.33 \% \text { of patients had poor moral } \\
\text { judgement performance) } \\
77.6 \% \text { of patients had non-social cognitive deficits } \\
\text { (i.e., executive domains) } \\
24 \% \text { of patients had social cognitive deficits }\end{array}$ \\
\hline Correlation analysis & $\begin{array}{l}\text { Significant positive correlation between } \\
\text { moral reactivity and MSSS scores } \\
\text { Significant positive correlation between } \\
\text { moral permissibility, empathy, and } \\
\text { alexithymia scores }\end{array}$ & $\begin{array}{l}\text { No significant correlation between moral } \\
\text { judgement and empathy or } \\
\text { alexithymia measures } \\
\text { Tendency toward negative correlation } \\
\text { between appropriateness of intentional } \\
\text { harm and alexithymia (did not survive } \\
\text { statistical corrections) } \\
\text { Significant negative correlation between } \\
\text { appropriateness of intentional harm and } \\
\text { empathy measures, perspective taking, } \\
\text { and empathic concern (did not survive } \\
\text { statistical corrections) }\end{array}$ & $\begin{array}{l}\text { Significant correlations between the attribution of } \\
\text { emotional valence and mentalizing (did not survive } \\
\text { statistical corrections) } \\
\text { No other correlations between moral judgment } \\
\text { and clinical, basic cognition, or social } \\
\text { cognition measures }\end{array}$ \\
\hline
\end{tabular}

BICAMS: Brief International Cognitive Assessment for Multiple Sclerosis battery; EDSS: Expanded Disability Status Scale; FSS: Fatigue Severity Scale; HADS: Hospital Anxiety and Depression Scale; IRI: Interpersonal Reactivity Index; MS: Multiple sclerosis; MuSIQoL: Multiple Sclerosis International Quality of Life; MSSS: Multiple Sclerosis Severity Score; N/A: Not available; RMET: Reading the Mind in the Eyes Test; RR: Relapsing remitting; TAS: Toronto Alexithymia Scale. 


\section{Current Conclusions and Future Perspectives}

Based on the very few available data, MS patients seem to have a different pattern of moral judgment compared to healthy individuals. More research is obviously needed to be able to replicate the observed pattern of moral judgment in large MS cohorts. Of note, the three examined cohorts consisted of patients suffering from RR MS and having low disability scores. The hallmark of the latter disease type is inflammation while PP and SP MS types are characterized by the predominance of neurodegeneration [7]. In fact, cognitive deficits are more pronounced in patients with progressive MS and the more severe levels of cognitive decline seems to happen during the progressive phase of the disease [106], prompting an investigation of morality in these MS phenotypes. Another issue concerns the disease modifying therapies, which may have some effects on cognitive functions [107] and deserve to be addressed as potential confounders in relation to moral cognition.

In addition, the cohorts consisted predominantly of adult women. Gender difference has been previously documented with regards to brain connectivity pattern, alexithymia, empathy, as well as moral judgment $[8,108,109]$. The impact of this factor is worth considering in future research, since gender and other sociodemographic variables, such as age and cultural differences, may lead to different patterns of moral judgment [48,110]. For instance, in one study, more utilitarian judgments were found among young participants compared to older ones [47], among men compared to women [47,48], and among Western men compared to Eastern men [47]. That is to say, differences across cultures may include regulatory social institutions (e.g., economic markets, kinship structures) and social ecology (e.g., population density, residential mobility, prevalence of pathogens, weather and other environmental factors) [110]. Genetic variation may also contribute to study outcomes [17,18].

Therefore, future studies could benefit from measuring moral cognition in larger MS cohorts with different disease phenotypes and applying comprehensive neuropsychological batteries to understand the relationship between moral cognition and other cognitive and socio-emotional domains, as well as clinical, cultural, and demographic characteristics.

Regarding the assessment of moral judgment, different assessment tools have been employed across the studies and may yield different moral judgments [32]. Standardizing tasks would be of help, since different tasks (e.g., task type and complexity) render it difficult to compare results across the studies. Moreover, adopting an ecological approach and increasing the apparent validity of dilemmas might be possible by adapting immersive virtual environments that more resemble real-life settings compared to stories that might not reflect how individuals behave in a more enriched social context $[37,111]$.

Furthermore, in the absence of any study assessing the underlying mechanisms of moral judgment in this population, future application of different neuroimaging modalities, such as functional magnetic resonance imaging, diffusion-weighted imaging tractography, or voxel-based morphometry, would be of great interest in order to decipher the neural underpinnings of morality in MS patients. Neurophysiological techniques, such as high-density electroencephalography [112], autonomic assessment (e.g., cardiovagal tone, peripheral vascular resistance, skin conduction response) [34-38], or transient neuromodulation using noninvasive brain stimulation (NIBS), may also serve this purpose [113]. A research design for future studies is suggested in Figure A1.

Finally, if future research concludes a serious impact of aberrant moral judgment on patients' daily life and social function, attention should be paid on finding therapeutic solutions. Studies in healthy volunteers and other clinical populations have tested the effects of (i) pharmacological molecules, (ii) psychotherapies, and (iii) NIBS techniques on moral judgment. For instance, the administration of hormones (i.e., testosterone) [114,115], neuropeptides (e.g., oxytocin) [43], or other drugs that enhance neurotransmission (i.e., serotonin-specific reuptake inhibitors [43,44], dopamine precursors [44], noradrenergic beta-adrenoceptor antagonists [46], gamma aminobutyric acid (GABA) agonists [116]) were found to modulate the pattern of moral judgment, but the direction of moral judgment changes (utilitarian versus deontological) varied across the studies. Other than medications, NIBS techniques have recently emerged as appealing therapeutic interventions in several neuropsychiatric conditions, 
including MS [7,113,117-120], and might have their place in modulating moral judgment deficits. By transcranially applying an electric current or a magnetic field, NIBS modulates the functions of several cerebral areas $[7,113,117-120]$. The application of NIBS over cortical areas that take part in moral judgment networks, such as dorsolateral PFC [121-125]), ventral PFC [126], or TPJ [127-131], have also resulted in some changes in moral judgment performance. However, the protocols differed in their design, stimulation parameters, and targeted areas, and yielded conflicting and sometimes negative results. Although incongruent, these preliminary findings give some hope for the possibility of using these techniques to improve moral judgment. The implication of physiological arousal in moral judgment suggests a third category of interventions. In fact, mindfulness-based interventions, biofeedback, and cognitive behavioral therapy or some of its components (i.e., cognitive reappraisal techniques) have been applied in MS [132-134] and might be helpful to train bodily signals, which seem to play a role in moral reasoning. However, facing all these possible interventions, one should keep in mind that shaping morality could raise serious ethical concerns [135], and setting regulations is warranted to meet this concern [18].

Author Contributions: Both authors contributed equally in reviewing literature, analyzing the data and writing the manuscript.

Funding: This research received no external funding.

Conflicts of Interest: S.S.A. declares having received travel grants or compensation from Genzyme, Biogen, Novartis and Roche. M.A.C. declares no conflict of interest. 


\section{Appendix A}

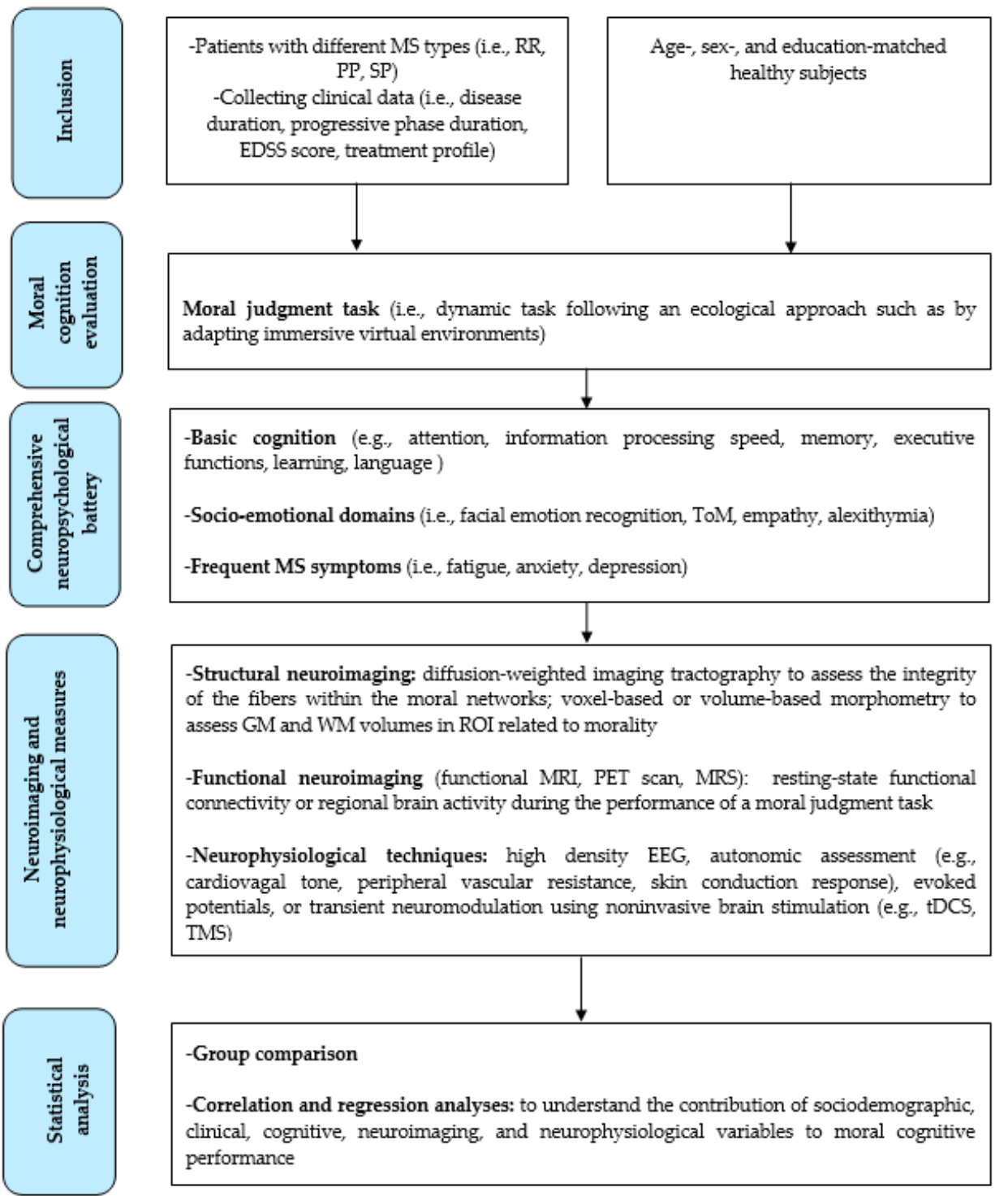

Figure A1. A proposed roadmap for future research addressing moral cognition in multiple sclerosis. EDSS: Expanded Disability Status Scale; EEG: electroencephalography; MRI: magnetic resonance imaging; MRS: magnetic resonance spectroscopy; MS: multiple sclerosis; RR: relapsing remitting; PET: positron emission tomography; PP: primary progressive; ROI: region of interest; SP: secondary progressive; tDCS: transcranial direct current stimulation; TMS: transcranial magnetic stimulation; ToM: theory of mind.

\section{References}

1. Compston, A.; Coles, A. Multiple sclerosis. Lancet 2008, 372, 1502-1517. [CrossRef]

2. Chalah, M.A.; Ayache, S.S. Is there a link between inflammation and fatigue in multiple sclerosis? J. Inflamm. Res. 2018, 11, 253-264. [CrossRef] [PubMed]

3. Centonze, D.; Muzio, L.; Rossi, S.; Furlan, R.; Bernardi, G.; Martino, G. The link between inflammation, synaptic transmission and neurodegeneration in multiple sclerosis. Cell Death Differ. 2010, 17, 1083-1091. [CrossRef] [PubMed]

4. Dendrou, C.A.; Fugger, L.; Friese, M.A. Immunopathology of multiple sclerosis. Nat. Rev. Immunol. 2015, 15, 545-558. [CrossRef] [PubMed] 
5. Segal, B.M.; Stüve, O. Primary progressive multiple sclerosis-Why we are failing. Lancet 2016, 387, 1032-1034. [CrossRef]

6. Chalah, M.A.; Ayache, S.S. Psychiatric event in multiple sclerosis: Could it be the tip of the iceberg? Rev. Bras. Psiquiatr. 2017, 39, 365-368. [CrossRef] [PubMed]

7. Chalah, M.A.; Riachi, N.; Ahdab, R.; Créange, A.; Lefaucheur, J.P.; Ayache, S.S. Fatigue in Multiple Sclerosis: Neural Correlates and the Role of Non-Invasive Brain Stimulation. Front. Cell. Neurosci. 2015, 9, 460. [CrossRef] [PubMed]

8. Chalah, M.A.; Ayache, S.S. Alexithymia in multiple sclerosis: A systematic review of literature. Neuropsychologia 2017, 104, 31-47. [CrossRef] [PubMed]

9. Rao, S.M.; Leo, G.J.; Bernardin, L.; Unverzagt, F. Cognitive dysfunction in multiple sclerosis. I. Frequency, patterns, and prediction. Neurology 1991, 41, 685-691. [CrossRef] [PubMed]

10. Rao, S.M.; Leo, G.J.; Ellington, L.; Nauertz, T.; Bernardin, L.; Unverzagt, F. Cognitive dysfunction in multiple sclerosis. II. Impact on employment and social functioning. Neurology 1991, 41, 692-696. [CrossRef] [PubMed]

11. Benedict, R.H.; Cookfair, D.; Gavett, R.; Gunther, M.; Munschauer, F.; Garg, N.; Weinstock-Guttman, B. Validity of the minimal assessment of cognitive function in multiple sclerosis (MACFIMS). J. Int. Neuropsychol. Soc. 2006, 12, 549-558. [CrossRef] [PubMed]

12. Sanfilipo, M.P.; Benedict, R.H.; Weinstock-Guttman, B.; Bakshi, R. Gray and white matter brain atrophy and neuropsychological impairment in multiple sclerosis. Neurology 2006, 66, 685-692. [CrossRef] [PubMed]

13. Chalah, M.A.; Ayache, S.S. Deficits in Social Cognition: An Unveiled Signature of Multiple Sclerosis. J. Int. Neuropsychol. Soc. 2017, 23, 266-286. [CrossRef] [PubMed]

14. Kalb, R.C. Multiple Sclerosis: A Guide for Families; Demos Medical Publishing: New York, NY, USA, 2005.

15. Moll, J.; Zahn, R.; de Oliveira-Souza, R.; Krueger, F.; Grafman, J. Opinion: The neural basis of human moral cognition. Nat. Rev. Neurosci. 2005, 6, 799-809. [CrossRef] [PubMed]

16. Moher, D.; Liberati, A.; Tetzlaff, J.; Altman, D.G. Group PRISMA. Preferred reporting items for systematic reviews and metaanalyses: The PRISMA statement. PLoS Med. 2009, 6, e1000097. [CrossRef] [PubMed]

17. Pascual, L.; Rodrigues, P.; Gallardo-Pujol, D. How does morality work in the brain? A functional and structural perspective of moral behavior. Front. Integr. Neurosci. 2013, 7, 65. [CrossRef] [PubMed]

18. Fumagalli, M.; Priori, A. Functional and clinical neuroanatomy of morality. Brain 2012, 135, $2006-2021$. [CrossRef] [PubMed]

19. Hutcherson, C.A.; Montaser-Kouhsari, L.; Woodward, J.; Rangel, A. Emotional and Utilitarian Appraisals of Moral Dilemmas Are Encoded in Separate Areas and Integrated in Ventromedial Prefrontal Cortex. J. Neurosci. 2015, 35, 12593-12605. [CrossRef] [PubMed]

20. Cohen, D.J.; Ahn, M. A subjective utilitarian theory of moral judgment. J. Exp. Psychol. Gen. 2016, 145, 1359-1381. [CrossRef] [PubMed]

21. Greene, J.; Sommerville, R.B.; Nystrom, L.E.; Darley, J.M.; Cohen, J.D. An fMRI investigation of emotional engagement in moral judgment. Science 2001, 293, 2105-2108. [CrossRef] [PubMed]

22. Greene, J. Emotion and cognition in moral judgment: Evidence from neuroimaging. In Neurobiology of Human Values; Springer: Berlin, Heidelberg, Germany, 2005; Volume 66, pp. 57-66. [CrossRef]

23. Greene, J.D.; Morelli, S.A.; Lowenberg, K.; Nystrom, L.E.; Cohen, J.D. Cognitive load selectively interferes with utilitarian moral judgment. Cognition 2008, 107, 1144-1154. [CrossRef] [PubMed]

24. Haidt, J. The emotional dog and its rational tail: A social intuitionist approach to moral judgment. Psychol. Rev. 2001, 108, 814-834. [CrossRef] [PubMed]

25. De Neys, W.; Glumicic, T. Conflict monitoring in dual process theories of reasoning. Cognition 2008, 106, 1248-1299. [CrossRef] [PubMed]

26. Cushman, F. Action, outcome, and value: A dual-system framework for morality. Pers. Soc. Psychol. Rev. 2013, 17, 273-292. [CrossRef] [PubMed]

27. Greene, J.; Nystrom, L.E.; Engell, A.D.; Darley, J.M.; Cohen, J.D. The neural bases of cognitive conflict and control in moral judgment. Neuron 2004, 44, 389-400. [CrossRef] [PubMed]

28. Ciaramelli, E.; Muccioli, M.; Làdavas, E.; di Pellegrino, G. Selective deficit in personal moral judgment following damage to ventromedial prefrontal cortex. Soc. Cogn. Affect. Neurosci. 2007, 2, 84-92. [CrossRef] [PubMed]

29. Koenigs, M.; Young, L.; Adolphs, R.; Tranel, D.; Cushman, F.; Hauser, M.; Damasio, A. Damage to the prefrontal cortex increases utilitarian moral judgements. Nature 2007, 446, 908-911. [CrossRef] [PubMed] 
30. Van Bavel, J.J.; Feldmanhall, O.; Mende-Siedlecki, P. The neuroscience of moral cognition: From dual processes to dynamic systems. Curr. Opin. Psychol. 2015, 6, 167-172. [CrossRef]

31. Buckholtz, J.W.; Marois, R. The roots of modern justice: Cognitive and neural foundations of social norms and their enforcement. Nat. Neurosci. 2012, 15, 655-661. [CrossRef] [PubMed]

32. Eres, R.; Louis, W.R.; Molenberghs, P. Common and distinct neural networks involved in fMRI studies investigating morality: An ALE meta-analysis. Soc. Neurosci. 2018, 384-398. [CrossRef] [PubMed]

33. Tsoi, L.; Dungan, J.A.; Chakroff, A.; Young, L.L. Neural substrates for moral judgments of psychological versus physical harm. Soc. Cogn. Affect. Neurosci. 2018, 13, 460-470. [CrossRef] [PubMed]

34. Carmona-Perera, M.; Reyes del Paso, G.A.; Pérez-García, M.; Verdejo-García, A. Heart rate correlates of utilitarian moral decision-making in alcoholism. Drug Alcohol Depend. 2013, 133, 413-419. [CrossRef] [PubMed]

35. Park, G.; Kappes, A.; Rho, Y.; Van Bavel, J.J. At the heart of morality lies neuro-visceral integration: Lower cardiac vagal tone predicts utilitarian moral judgment. Soc. Cogn. Affect. Neurosci. 2016, 11, 1588-1596. [CrossRef] [PubMed]

36. Moretto, G.; Làdavas, E.; Mattioli, F.; Di Pellegrino, G. A psychophysiological investigation of moral judgment after ventromedial prefrontal damage. J. Cogn. Neurosci. 2010, 22, 1888-1899. [CrossRef] [PubMed]

37. Navarrete, C.D.; McDonald, M.M.; Mott, M.L.; Asher, B. Virtual morality: Emotion and action in a simulated three-dimensional "trolley problem". Emotion 2012, 12, 364-370. [CrossRef] [PubMed]

38. Cushman, F.; Gray, K.; Gaffey, A.; Mendes, W.B. Simulating murder: The aversion to harmful action. Emotion 2012, 12, 2-7. [CrossRef] [PubMed]

39. Gong, P.; Fang, P.; Yang, X.; Ru, W.; Wang, B.; Gao, X.; Liu, J. The CAG polymorphism in androgen receptor (AR) gene impacts the moral permissibility of harmful behavior in females. Psychoneuroendocrinology 2017, 80, 74-79. [CrossRef] [PubMed]

40. Bernhard, R.M.; Chaponis, J.; Siburian, R.; Gallagher, P.; Ransohoff, K.; Wikler, D.; Perlis, R.H.; Greene, J.D. Variation in the oxytocin receptor gene (OXTR) is associated with differences in moral judgment. Soc. Cogn. Affect. Neurosci. 2016, 11, 1872-1881. [CrossRef] [PubMed]

41. Walter, N.T.; Montag, C.; Markett, S.; Felten, A.; Voigt, G.; Reuter, M. Ignorance is no excuse: Moral judgments are influenced by a genetic variation on the oxytocin receptor gene. Brain Cogn. 2012, 78, 268-273. [CrossRef] [PubMed]

42. Scheele, D.; Striepens, N.; Kendrick, K.M.; Schwering, C.; Noelle, J.; Wille, A.; Schläpfer, T.E.; Maier, W.; Hurlemann, R. Opposing effects of oxytocin on moral judgment in males and females. Hum. Brain Mapp. 2014, 35, 6067-6076. [CrossRef] [PubMed]

43. Crockett, M.J.; Clark, L.; Hauser, M.D.; Robbins, T.W. Serotonin selectively influences moral judgment and behavior through effects on harm aversion. Proc. Natl. Acad. Sci. USA 2010, 107, 17433-17438. [CrossRef] [PubMed]

44. Crockett, M.J.; Siegel, J.Z.; Kurth-Nelson, Z.; Ousdal, O.T.; Story, G.; Frieband, C.; Grosse-Rueskamp, J.M.; Dayan, P.; Dolan, R.J. Dissociable Effects of Serotonin and Dopamine on the Valuation of Harm in Moral Decision Making. Curr. Biol. 2015, 25, 1852-1859. [CrossRef] [PubMed]

45. Siegel, J.Z.; Crockett, M.J. How serotonin shapes moral judgment and behavior. Ann. N. Y. Acad. Sci. 2013, 1299, 42-51. [CrossRef] [PubMed]

46. Terbeck, S.; Kahane, G.; McTavish, S.; Savulescu, J.; Levy, N.; Hewstone, M.; Cowen, P.J. Beta adrenergic blockade reduces utilitarian judgement. Biol. Psychol. 2013, 92, 323-328. [CrossRef] [PubMed]

47. Arutyunova, K.R.; Alexandrov, Y.I.; Hauser, M.D. Sociocultural Influences on Moral Judgments: East-West, Male-Female, and Young-Old. Front. Psychol. 2016, 7, 1334. [CrossRef] [PubMed]

48. Youssef, F.F.; Dookeeram, K.; Basdeo, V.; Francis, E.; Doman, M.; Mamed, D.; Maloo, S.; Degannes, J.; Dobo, L.; Ditshotlo, P.; et al. Stress alters personal moral decision making. Psychoneuroendocrinology 2012, 37, 491-498. [CrossRef] [PubMed]

49. Thomson, J.J. The trolley problem. Yale Law J. 1985, 94, 1395-1415. [CrossRef]

50. Brink, D.O. Utilitarian morality and the personal point of view. J. Philos. 1986, 83, 417-438. [CrossRef]

51. Foot, P. The problem of abortion and the doctrine of double effect. In Virtues and Vices; Blackwell: Oxford, UK, 1978.

52. Thomson, J.J. Rights, Restitution, and Risk: Essays in Moral Theory; Harvard: Cambridge, MA, USA, 1986.

53. Suter, R.S.; Hertwig, R. Time and moral judgment. Cognition 2011, 119, 454-458. [CrossRef] [PubMed] 
54. Paxton, J.M.; Ungar, L.; Greene, J.D. Reflection and reasoning in moral judgment. Cogn. Sci. 2012, 36, $163-177$. [CrossRef] [PubMed]

55. Decety, J.; Michalska, K.J.; Kinzler, K.D. The contribution of emotion and cognition to moral sensitivity: A neurodevelopmental study. Cereb. Cortex 2011, 22, 209-220. [CrossRef] [PubMed]

56. Pujol, J.; Batalla, I.; Contreras-Rodríguez, O.; Harrison, B.J.; Pera, V.; Hernández-Ribas, R.; Real, E.; Bosa, L.; Soriano-Mas, C.; Deus, J.; et al. Breakdown in the brain network subserving moral judgment in criminal psychopathy. Soc. Cogn. Affect. Neurosci. 2011, 7, 917-923. [CrossRef] [PubMed]

57. Lotto, L.; Manfrinati, A.; Sarlo, M. A new set of moral dilemmas: Norms for moral acceptability, decision times, and emotional salience. J. Behav. Decis. Mak. 2014, 27, 57-65. [CrossRef]

58. Moll, J.; Eslinger, P.J.; Oliveira-Souza, R. Frontopolar and anterior temporal cortex activation in a moral judgment task: Preliminary functional MRI results in normal subjects. Arq. Neuropsiquiatr. 2001, 59, 657-664. [CrossRef] [PubMed]

59. Harenski, C.L.; Hamaan, S. Neural correlates of regulating negative emotions related to moral violations. Neuroimage 2006, 30, 313-324. [CrossRef] [PubMed]

60. Rush, J.A.; First, M.B.; Blacker, D. Handbook of Psychiatric Measures; American Psychiatric Publishing: Washington, DC, USA, 2008.

61. Gleichgerrcht, E.; Tomashitis, B.; Sinay, V. The relationship between alexithymia, empathy and moral judgment in patients with multiple sclerosis. Eur. J. Neurol. 2015, 22, 1295-1303. [CrossRef] [PubMed]

62. Patil, I.; Young, L.; Sinay, V.; Gleichgerrcht, E. Elevated moral condemnation of third-party violations in multiple sclerosis patients. Soc. Neurosci. 2017, 12, 308-329. [CrossRef] [PubMed]

63. Realmuto, S.; Dodich, A.; Meli, R.; Canessa, N.; Ragonese, P.; Salemi, G.; Cerami, C. Moral Cognition and Multiple Sclerosis: A Neuropsychological Study. Arch. Clin. Neuropsychol. 2018. [CrossRef] [PubMed]

64. Koven, N.S. Specificity of meta-emotion effects on moral decision-making. Emotion 2011, 11, $1255-1261$. [CrossRef] [PubMed]

65. Knobe, J. Theory of mind and moral cognition: Exploring the connections. Trends Cogn. Sci. 2005, 9, 357-359. [CrossRef] [PubMed]

66. Forbes, C.E.; Grafman, J. The role of the human prefrontal cortex in social cognition and moral judgment. Annu. Rev. Neurosci. 2010, 33, 299-324. [CrossRef] [PubMed]

67. Young, L.; Dungan, J. Where in the brain is morality? Everywhere and maybe nowhere. Soc. Neurosci. 2011, 7, 1-10. [CrossRef] [PubMed]

68. Valdesolo, P.; DeSteno, D. Manipulations of emotional context shape moral judgment. Psychol. Sci 2006, 17, 476-477. [CrossRef] [PubMed]

69. Mendez, M.F.; Anderson, E.; Shapira, J.S. An investigation of moral judgement in frontotemporal dementia. Cogn. Behav. Neurol. 2005, 18, 193-197. [CrossRef] [PubMed]

70. Kahane, G.; Shackel, N. Do abnormal responses show utilitarian bias? Nature 2008, 452, E5. [CrossRef] [PubMed]

71. Gleichgerrcht, E.; Torralva, T.; Rattazzi, A.; Marenco, V.; Roca, M.; Manes, F. Selective impairment of cognitive empathy for moral judgment in adults with high functioning autism. Soc. Cogn. Affect. Neurosci. 2013, 8, 780-788. [CrossRef] [PubMed]

72. Gleichgerrcht, E.; Torralva, T.; Roca, M.; Pose, M.; Manes, F. The role of social cognition in moral judgment in frontotemporal dementia. Soc. Neurosci. 2011, 6, 113-122. [CrossRef] [PubMed]

73. Gleichgerrcht, E.; Young, L. Low levels of empathic concern predict utilitarian moral judgment. PLoS ONE 2013, 8, e60418. [CrossRef] [PubMed]

74. Charil, A.; Zijdenbos, A.P.; Taylor, J.; Boelman, C.; Worsley, K.J.; Evans, A.C.; Dagher, A. Statistical mapping analysis of lesion location and neurological disability in multiple sclerosis: Application to 452 patient data sets. NeuroImage 2003, 19, 532-544. [CrossRef]

75. Pagani, E.; Rocca, M.A.; Gallo, A.; Rovaris, M.; Martinelli, V.; Comi, G.; Filippi, M. Regional brain atrophy evolves differently in patients with multiple sclerosis according to clinical phenotype. Am. J. Neuroradiol. 2005, 26, 341-346. [PubMed]

76. Sethi, V.; Yousry, T.A.; Muhlert, N.; Tozer, D.; Ron, M.; Golay, X.; Wheeler-Kingshott, C.; Miller, D.H.; Chard, D.T. Lobar distribution of cortical grey matter lesions in multiple sclerosis clinical subgroups. J. Neurol. Neurosurg. Psychiatry 2013, 84, e2. [CrossRef] 
77. Krause, M.; Wendt, J.; Dressel, A.; Berneiser, J.; Kessler, C.; Hamm, A.O.; Lotze, M. Prefrontal function associated with impaired emotion recognition in patients with multiple sclerosis. Behav. Brain Res. 2009, 205, 280-285. [CrossRef] [PubMed]

78. Batista, S.; Alves, C.; d'Almeida, O.C.; Afonso, A.; Félix-Morais, R.; Pereira, J.; Macário, C.; Sousa, L.; Castelo-Branco, M.; Santana, I.; et al. Disconnection as a mechanism for social cognition impairment in multiple sclerosis. Neurology 2017, 89, 38-45. [CrossRef] [PubMed]

79. Chalah, M.A.; Kauv, P.; Lefaucheur, J.P.; Hodel, J.; Créange, A.; Ayache, S.S. Theory of mind in multiple sclerosis: A neuropsychological and MRI study. Neurosci. Lett. 2017, 658, 108-113. [CrossRef] [PubMed]

80. Mike, A.; Strammer, E.; Aradi, M.; Orsi, G.; Perlaki, G.; Hajnal, A.; Sandor, J.; Banati, M.; Illes, E.; Zaitsev, A.; et al. Disconnection mechanism and regional cortical atrophy contribute to impaired processing of facial expressions and theory of mind in multiple sclerosis: A structural MRI study. PLoS ONE 2013, 8, e82422. [CrossRef] [PubMed]

81. Batista, S.; d'Almeida, O.C.; Afonso, A.; Freitas, S.; Macário, C.; Sousa, L.; Castelo-Branco, M.; Santana, I.; Cunha, L. Impairment of social cognition in multiple sclerosis: Amygdala atrophy is the main predictor. Mult. Scler. 2017, 23, 1358-1366. [CrossRef] [PubMed]

82. Passamonti, L.; Cerasa, A.; Liguori, M.; Gioia, M.; Valentino, P.; Nisticò, R.; Nistico, R.; Quattrone, A.; Fera, F. Neurobiological mechanisms underlying emotional processing in relapsing-remitting multiple sclerosis. Brain 2009, 132, 3380-3391. [CrossRef] [PubMed]

83. Jehna, M.; Neuper, C.; Ischebeck, A.; Loitfelder, M.; Ropele, S.; Langkammer, C.; Langkammer, C.; Ebner, F.; Fuchs, S.; Schmidt, R.; et al. The functional correlates of face perception and recognition of emotional facial expressions as evidenced by fMRI. Brain Res. 2011, 1393, 73-83. [CrossRef] [PubMed]

84. Phillips, L.H.; Saldias, A.; McCarrey, A.; Henry, J.D.; Scott, C.; Summers, F.; Whyte, M. Attentional lapses, emotional regulation and quality of life in multiple sclerosis. Br. J. Clin. Psychol. 2009, 48, 101-106. [CrossRef] [PubMed]

85. Phillips, L.H.; Henry, J.D.; Nouzova, E.; Cooper, C.; Radlak, B.; Summers, F. Difficulties with emotion regulation in multiple sclerosis: Links to executive function, mood, and quality of life. J. Clin. Exp. Neuropsychol. 2014, 36, 831-842. [CrossRef] [PubMed]

86. Henry, A.; Tourbah, A.; Chaunu, M.-P.; Bakchine, S.; Montreuil, M. Social Cognition Abilities in Patients With Different Multiple Sclerosis Subtypes. J. Int. Neuropsychol. Soc. 2017, 23, 653-664. [CrossRef] [PubMed]

87. Schirda, B.; Nicholas, J.A.; Prakash, R.S. Examining trait mindfulness, emotion dysregulation, and quality of life in multiple sclerosis. Health Psychol. 2015, 34, 1107-1115. [CrossRef] [PubMed]

88. Young, L.; Bechara, A.; Tranel, D.; Damasio, H.; Hauser, M.; Damasio, A. Damage to ventromedial prefrontal cortex impairs judgment of harmful intent. Neuron 2010, 65, 845-851. [CrossRef] [PubMed]

89. Chahraoui, K.; Duchene, C.; Rollot, F.; Bonin, B.; Moreau, T. Longitudinal study of alexithymia and multiple sclerosis. Brain Behav. 2014, 4, 75-82. [CrossRef] [PubMed]

90. Sá, M.J. Psychological aspects of multiple sclerosis. Clin. Neurol. Neurosurg. 2008, 110, 868-877. [CrossRef] [PubMed]

91. Luminet, O.; Rimé, B.; Bagby, R.M.; Taylor, G. A multimodal investigation of emotional responding in alexithymia. Cogn. Emot. 2004, 18, 741-766. [CrossRef]

92. Demers, L.A.; Koven, N.S. The Relation of Alexithymic Traits to Affective Theory of Mind. Am. J. Psychol. 2015, 128, 31-42. [CrossRef] [PubMed]

93. McCabe, M.P.; Stokes, M.; McDonald, E. Changes in quality of life and coping among people with multiple sclerosis over a 2 year period. Psychol. Health Med. 2009, 14, 86-96. [CrossRef] [PubMed]

94. Kurtzke, J.F. Rating neurologic impairment in multiple sclerosis: An expanded disability status scale (EDSS). Neurology 1983, 33, 1444-1452. [CrossRef] [PubMed]

95. Roxburgh, R.H.S.R.; Seaman, S.R.; Masterman, T.; Hensiek, A.E.; Sawcer, S.J.; Vukusic, S.; Achiti, I.; Confavreux, C.; Coustans, M.; Le Page, E.; et al. Multiple Sclerosis Severity Score: Using disability and disease duration to rate disease severity. Neurology 2005, 64, 1144-1151. [CrossRef] [PubMed]

96. Bagby, R.M.; Parker, J.D.; Taylor, G.J. The twenty-item Toronto Alexithymia Scale-I. Item selection and crossvalidation of the factor structure. J. Psychosom. Res. 1994, 38, 23-32. [CrossRef]

97. Davis, M.H. Measuring individual differences in empathy: Evidence for a multidimensional approach. J. Pers. Soc. Psychol. 1983, 44, 113-126. [CrossRef] 
98. Goretti, B.; Niccolai, C.; Hakiki, B.; Sturchio, A.; Falautano, M.; Minacapelli, E.; Martinelli, V.; Incerti, C.; Nocentini, U.; Murgia, M.; et al. The Brief International Cognitive Assessment for Multiple Sclerosis (BICAMS): Normative values with gender, age and education corrections in the Italian population. BMC Neurol. 2014, 14, 171. [CrossRef] [PubMed]

99. Della Sala, S.; MacPherson, S.; Phillips, L.; Sacco, L.; Spinnler, H. How many camels are there in Italy? Cognitive estimates standardised on the Italian population. Neurol. Sci. 2003, 24, 10-15. [CrossRef] [PubMed]

100. Caffarra, P.; Vezzadini, G.; Dieci, F.; Zonato, F.; Venneri, A. Una versione abbreviata del test di Stroop: Dati normativi nella popolazione italiana. Nuova Rivista di Neurologia 2002, 12, 111-115.

101. Dodich, A.; Cerami, C.; Canessa, N.; Crespi, C.; Iannaccone, S.; Marcone, A.; Realmuto, S.; Lettieri, G.; Perani, D.; Cappa, S.F. A novel task assessing intention and emotion attribution: Italian standardization and normative data of the Story-based Empathy Task. Neurol. Sci. 2015, 36, 1907-1912. [CrossRef] [PubMed]

102. Dodich, A.; Cerami, C.; Canessa, N.; Crespi, C.; Marcone, A.; Arpone, M.; Realmuto, S.; Cappa, S.F. Emotion recognition from facial expressions: A normative study of the Ekman 60-Faces Test in the Italian population. Neurol. Sci. 2014, 35, 1015-1021. [CrossRef] [PubMed]

103. Simeoni, M.; Auquier, P.; Fernandez, O.; Flachenecker, P.; Stecchi, S.; Constantinescu, C.; Idiman, E.; Boyko, A.; Beiske, A.G.; Vollmer, T.; et al. Validation of the Multiple Sclerosis International Quality of Life questionnaire. Mult. Scler. 2008, 14, 219-230. [CrossRef] [PubMed]

104. Krupp, L.B.; Coyle, P.K.; Doscher, C.; Miller, A.; Cross, A.H.; Jandorf, L.; Halper, J.; Johnson, B.; Morgante, L.; Grimson, R. Fatigue therapy in multiple sclerosis: Results of a double-blind, randomized, parallel trial of amantadine, pemoline, and placebo. Neurology 1995, 45, 1956-1961. [CrossRef] [PubMed]

105. Zigmond, A.S.; Snaith, R.P. The hospital anxiety and depression scale. Acta Psychiatr. Scand. 1983, 67, 361-370. [CrossRef] [PubMed]

106. Langdon, D.W. Cognition in multiple sclerosis. Curr. Opin. Neurol. 2011, 2011 24, 244-249. [CrossRef]

107. Comi, G. Effects of disease modifying treatments on cognitive dysfunction in multiple sclerosis. Neurol. Sci. 2010, 31 (Suppl. 2), S261-S264. [CrossRef] [PubMed]

108. Tomasi, D.; Volkow, N.D. Gender differences in brain functional connectivity density. Hum Brain Mapp. 2012, 33, 849-860. [CrossRef] [PubMed]

109. Lennon, R.; Eisenberg, N. Gender and age differences in empathy and sympathy. In Empathy and its Development; Eisenberg, N., Strayer, J., Eds.; Cambridge University Press: Cambridge, UK, 1987.

110. Graham, J.; Meindl, P.; Beall, E.; Johnson, K.M.; Zhang, L. Cultural differences in moral judgment and behavior, across and within societies. Curr. Opin. Psychol. 2016, 8, 125-130. [CrossRef] [PubMed]

111. Slater, M.; Antley, A.; Davison, A.; Swapp, D.; Guger, C.; Barker, C.; Pistrang, N.; Sanchez-Vives, M.V. A virtual reprise of the Stanley Milgram obedience experiments. PLoS ONE 2006, 1, e39. [CrossRef]

112. Yoder, K.J.; Decety, J. Spatiotemporal neural dynamics of moral judgment: A high-density ERP study. Neuropsychologia 2014, 60, 39-45. [CrossRef] [PubMed]

113. Rossini, P.M.; Burke, D.; Chen, R.; Cohen, L.G.; Daskalakis, Z.; Di Iorio, R.; Di Lazzaro, V.; Ferreri, F.; Fitzgerald, P.B.; George, M.S.; et al. Non-invasive electrical and magnetic stimulation of the brain, spinal cord, roots and peripheral nerves: Basic principles and procedures for routine clinical and research application. An updated report from an IFCN Committee. Clin. Neurophysiol. 2015, 126, 1071-1107. [CrossRef] [PubMed]

114. Montoya, E.R.; Terburg, D.; Bos, P.A.; Will, G.J.; Buskens, V.; Raub, W.; van Honk, J. Testosterone administration modulates moral judgments depending on second-to-fourth digit ratio. Psychoneuroendocrinology 2013, 38, 1362-1369. [CrossRef] [PubMed]

115. Chen, C.; Decety, J.; Huang, P.C.; Chen, C.Y.; Cheng, Y. Testosterone administration in females modulates moral judgment and patterns of brain activation and functional connectivity. Hum. Brain Mapp. 2016, 37, 3417-3430. [CrossRef] [PubMed]

116. Perkins, A.M.; Leonard, A.M.; Weaver, K.; Dalton, J.A.; Mehta, M.A.; Kumari, V.; Williams, S.C.; Ettinger, U. A dose of ruthlessness: Interpersonal moral judgment is hardened by the anti-anxiety drug lorazepam. J. Exp. Psychol. Gen. 2013, 142, 612-620. [CrossRef] [PubMed]

117. Ayache, S.S.; Chalah, M.A. Transcranial direct current stimulation: A glimmer of hope for multiple sclerosis fatigue? J. Clin. Neurosci. 2018. [CrossRef] [PubMed]

118. Ayache, S.S.; Chalah, M.A. Fatigue in multiple sclerosis-Insights into evaluation and management. Neurophysiol. Clin. 2017, 47, 139-171. [CrossRef] [PubMed] 
119. Lefaucheur, J.P.; Antal, A.; Ayache, S.S.; Benninger, D.H.; Brunelin, J.; Cogiamanian, F.; Cotelli, M.; De Ridder, D.; Ferrucci, R.; Langguth, B.; et al. Evidence-based guidelines on the therapeutic use of transcranial direct current stimulation (tDCS). Clin. Neurophysiol. 2017, 128, 56-92. [CrossRef] [PubMed]

120. Lefaucheur, J.P.; Chalah, M.A.; Mhalla, A.; Palm, U.; Ayache, S.S.; Mylius, V. The treatment of fatigue by non-invasive brain stimulation. Neurophysiol. Clin. 2017, 47, 173-184. [CrossRef] [PubMed]

121. Jeurissen, D.; Sack, A.T.; Roebroeck, A.; Russ, B.E.; Pascual-Leone, A. TMS affects moral judgment, showing the role of DLPFC and TPJ in cognitive and emotional processing. Front. Neurosci. 2014, 8, 18. [CrossRef] [PubMed]

122. Knoch, D.; Pascual-Leone, A.; Meyer, K.; Treyer, V.; Fehr, E. Diminishing reciprocal fairness by disrupting the right prefrontal cortex. Science 2006, 314, 829-832. [CrossRef] [PubMed]

123. Zheng, H.; Lu, X.; Huang, D. tDCS Over DLPFC Leads to Less Utilitarian Response in Moral-Personal Judgment. Front. Neurosci. 2018, 12, 193. [CrossRef] [PubMed]

124. Kuehne, M.; Heimrath, K.; Heinze, H.J.; Zaehle, T. Transcranial direct current stimulation of the left dorsolateral prefrontal cortex shifts preference of moral judgments. PLoS ONE 2015, 10, e0127061. [CrossRef] [PubMed]

125. Choy, O.; Raine, A.; Hamilton, R.H. Stimulation of the Prefrontal Cortex Reduces Intentions to Commit Aggression: A Randomized, Double-Blind, Placebo-Controlled, Stratified, Parallel-Group Trial. J. Neurosci. 2018, 38, 6505-6512. [CrossRef] [PubMed]

126. Fumagalli, M.; Vergari, M.; Pasqualetti, P.; Marceglia, S.; Mameli, F.; Ferrucci, R.; Mrakic-Sposta, S.; Zago, S.; Sartori, G.; Pravettoni, G.; et al. Brain switches utilitarian behavior: Does gender make the difference? PLoS ONE 2010, 5, e8865. [CrossRef] [PubMed]

127. Sellaro, R.; Güroğlu, B.; Nitsche, M.A.; van den Wildenberg, W.P.; Massaro, V.; Durieux, J.; Hommel, B.; Colzato, L.S. Increasing the role of belief information in moral judgments by stimulating the right temporoparietal junction. Neuropsychologia 2015, 77, 400-408. [CrossRef] [PubMed]

128. Ye, H.; Chen, S.; Huang, D.; Zheng, H.; Jia, Y.; Luo, J. Modulation of Neural Activity in the Temporoparietal Junction with Transcranial Direct Current Stimulation Changes the Role of Beliefs in Moral Judgment. Front. Hum. Neurosci. 2015, 9, 659. [CrossRef] [PubMed]

129. Leloup, L.; Miletich, D.D.; Andriet, G.; Vandermeeren, Y.; Samson, D. Cathodal Transcranial Direct Current Stimulation on the Right Temporo-Parietal Junction Modulates the Use of Mitigating Circumstances during Moral Judgments. Front. Hum. Neurosci. 2016, 10, 355. [CrossRef] [PubMed]

130. Noguchi, Y.; Oizumi, R. Electric stimulation of the right temporo-parietal junction induces a task-specific effect in deceptive behaviors. Neurosci. Res. 2018, 128, 33-39. [CrossRef] [PubMed]

131. Young, L.; Camprodon, J.A.; Hauser, M.; Pascual-Leone, A.; Saxe, R. Disruption of the right temporoparietal junction with transcranial magnetic stimulation reduces the role of beliefs in moral judgments. Proc. Natl. Acad. Sci. USA 2010, 107, 6753-6758. [CrossRef] [PubMed]

132. Simpson, R.; Booth, J.; Lawrence, M.; Byrne, S.; Mair, F.; Mercer, S. Mindfulness based interventions in multiple sclerosis-A systematic review. BMC Neurol. 2014, 14, 15. [CrossRef] [PubMed]

133. Mackay, A.M.; Buckingham, R.; Schwartz, R.S.; Hodgkinson, S.; Beran, R.G.; Cordato, D.J. The Effect of Biofeedback as a Psychological Intervention in Multiple Sclerosis: A Randomized Controlled Study. Int. J. MS Care 2015, 17, 101-108. [CrossRef] [PubMed]

134. Chalah, M.A.; Ayache, S.S. Cognitive behavioral therapies and multiple sclerosis fatigue: A review of literature. J. Clin. Neurosci. 2018, 52, 1-4. [CrossRef] [PubMed]

135. Presidents' Council on Bioethics. Beyond Therapy: Biotechnology and the Pursuit of Happiness; Government Printing Office: Washington, DC, USA, 2003.

(C) 2018 by the authors. Licensee MDPI, Basel, Switzerland. This article is an open access article distributed under the terms and conditions of the Creative Commons Attribution (CC BY) license (http:/ / creativecommons.org/licenses/by/4.0/). 